\title{
Effect of neem on Phyllocnistis citrella Stainton and its parasitoid Ageniaspis citricola Logvinovskaya in Ecuador
}

\section{(Efecto del nim sobre Phyllocnistis citrella Stainton y su parasitoide Ageniaspis citricola Logvinovskaya en Ecuador)}

\author{
Ernesto Cañarte-Bermúdez, ${ }^{1}$ Bernardo Navarrete-Cedeño, ${ }^{1}$ Silvia Montero-Cedeño, ${ }^{2}$ Hugo César \\ Arredondo-Bernal, ${ }^{3}$ Onésimo Chávez-López, ${ }^{4}$ Néstor Bautista-Martínez ${ }^{5}$
}

\begin{abstract}
Efficacy of neem on Citrus Leafminer (CLM) and effect on its parasitoid Ageniaspis citricola was evaluated, using field, cage and olfactometer tests. Treatments were: aqueous extract of neem $\left(50 \mathrm{gL}^{-1}\right)$, formulated oil of neem (10 $\left.\mathrm{mL} \mathrm{L}^{-1}\right)$ and control. Field study was done in a Citrus aurantifolia orchard, three applications were carried out, which were evaluated every 48 hours until ten days after the treatment. Cage and olfactometer tests were performed in a greenhouse and repeated twice each time. In the cage, it were used 50 infested Citrus reticulata plants per experimental unit, while for the olfactometer test, as experimental arena, transparent plastic jars with 20 adults of CLM inside were used. Variables evaluated were: CLM infestation, dead, live and predated larvae, pupae, emerged adults and parasitized pupal chambers. The highest mortality of the CLM was caused by the aqueous extract of neem with $77.17 \%$, which began 48 hours after application, suggesting inhibition of feeding. The aqueous extract of neem showed in average $88.80 \%$ of repellency of adults of CLM and neem oil $85.64 \%$. The high mortality of CLM and the repellent effect of neem, seem to influence negatively in parasitism which fluctuated between $9.45 \%$ and $20.16 \%$ in treated trees.
\end{abstract}

\section{Keywords}

Biological control, Botanical control, Citrus leaf miner.

\section{Resumen}

Se evaluó la eficacia del nim sobre el Minador de la Hoja de los Cítricos (MHC) y el efecto sobre su parasitoide Ageniaspis citricola mediante pruebas de campo, jaula y olfatómetro, los tratamientos fueron: extracto acuoso de nim (50 $\left.\mathrm{gL}^{-1}\right)$, aceite formulado de $\operatorname{nim}\left(10 \mathrm{~mL} \mathrm{~L}^{-1}\right)$, y un control. El experimento de campo se realizó en un huerto de limón Citrus aurantifolia, realizándose tres aplicaciones, que fueron evaluadas cada 48 horas hasta diez días después del tratamiento. Las pruebas en jaulas y olfatómetros se realizaron en invernadero, repitiéndose dos veces. En la jaula cada unidad experimental constó de 50 plantas de Citrus reticulata infestadas, en el olfatómetro, la arena experimental fue una botella de plástico transparente con 20 adultos de MHC en su interior. Las variables evaluadas fueron: infestación por MHC, larvas muertas, vivas y depredadas, pupas, adultos emergidos de MHC, y cámaras pupales parasitadas $\operatorname{con} A$. citricola. La mayor mortalidad del MHC (77.17\%) se registró con el extracto acuoso de nim, efecto que comenzó 48 horas después de la aplicación, actuando como inhibidor de la alimentación. El extracto acuoso de nim tuvo un resultado de $88.80 \%$ de repelencia de adultos de MHC y el aceite de nim $85.64 \%$. La alta mortalidad de MHC y el efecto repelente del nim influyeron negativamente en el parasitismo, que fluctuó entre 9.45 \% y 20.16\% en los árboles tratados.

\section{Palabras clave}

Control biológico, Control botánico, Minador de los cítricos. iniap.gob.ec)

2 Escuela Superior Politécnica Agropecuaria de Manabí, Carrera de Ingeniería Ambiental, Calceta-Ecuador (smontero@espam.edu.ec)

3 Centro Nacional de Referencia de Control Biológico, Tecomán-México (senasicatec@prodigy.net)

$4 \quad$ Consultor privado, México DF-México (one.chavez.lopez@gmail.com)

5 Colegio de Postgraduados, Texcoco-México (nestor@acolpos.mx) 


\section{Introduction}

The Citrus Leafminer (CLM) Phyllocnistis citrella Stainton (Lepidoptera: Gracillariidae), is an important pest of citrus, native from southern Asia, but today widespread in several countries producers of citrus in America, Africa, Europe and Oceania (Beattie and Hardy, 2004, Sarada et al., 2014). Direct damage is caused by the feeding of larvae which build serpentine-like tunnels, called mines, in the young leaves of trees of the Rutaceae family; in high infestations it is possible to find mines in branch and fruits; infested young trees can slow down their development by two to three years (Grafton-Cardwell et al., 2008; Dubreuil et al., 2018). Also is reported a significant interference with the photosynthetic function in infested plants (Arshad et al., 2018). As an indirect damage the lesions caused by CLM can facilitate the infection of bacterial diseases as the citrus canker Xanthomonas axonopodis pv. citri (Gottwald et al., 2007).

The CLM was reported in Ecuador in 1995. Nowadays is present in the main citrus producer zones of the country, that means that close to 10000 ha of citrus orchards are in potential risk due to the presence of the pest. Estimations of losses in Citrus aurantifolia reach the $45 \%$ and the higher rate of infestation is close to $100 \%$ (Valarezo and Cañarte 1998, Valarezo et al., 2004).

In order to satisfy the demand of products with high nutritious quality and low levels of pesticides, farmers should use good agricultural practices, which allow them to maximize productivity while protecting the environment (Green et al., 2016). In this context, the integrated use of botanical control and natural biological control becomes a good alternative for achieving this goal.

One of the most studied botanical insecticide is the neem (Azadirachta indica), a tree native of south Asia which has been used in ayurvedic medicine since the bronze age; this plant has many secondary metabolites with high biological activity like azadirachtin, meliacin, gedunin, salanin, nimbin and valassin (Ogbuewu et al., 2011). The research about the effect of neem compounds in pest control began in the firsts decades of the $20^{\text {th }}$ century and in the 60 $\mathrm{s}$ it was identified the azadirachtin which it is the most active metabolite (Valarezo et al, 2008). The mechanism of neem for control agricultural pest is mainly by phagodeterrency and reduction of fitness (Hummel et al., 2011). There are several studies that show the efficacy of neem derivates in CLM management (Borad et al., 2001, Faisal-Shareef et al., 2016, Arshad et al., 2019), these authors assign the success of neem compounds to their multiple mechanisms of action like the interference with insect molting and antifeedant effect.

Natural enemies play a key role in the regulation of CLM in Ecuador, in this country there are many predators and parasitoids that help to maintain the populations in subeconomic levels, the most important considering its efficacy is the encyrtid Ageniaspis citricola, an endoparasitoid widely used in many programs of classical biological control in several countries (Colmenarez et al., 2018), this parasitoid entered adventitiously in Ecuador when it was released in the north of Peru (Cañarte et al., 2004; Cañarte et al., 2005).

Taking into account the possibility of interference between biological and botanical control reported by Francesena and Schneiderab (2018) and Yanard (2019), this research was carried with the purpose of determinate the effectiveness of the neem on P. citrella and its compatibility with the activity of $A$. citricola, the main controller of this worldwide pest. 


\section{Methodology}

\section{Field test}

This experiment was carried out in a Citrus aurantifolia orchard in the Lodana Parish of the

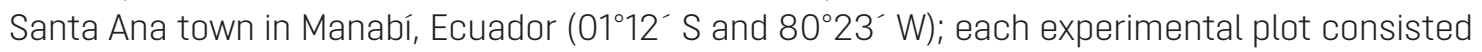
of nine six years old trees (separated seven meters between rows and seven meters between trees), being the central tree the useful one. The treatments were: aqueous extract of neem (50 gL-1), formulated neem oil Inbio $75^{\text {TM }}$-CEMADEC- $\left(10 \mathrm{~mL}^{-1}\right)$, and an absolute control (water). A randomized complete block design was used, with four blocks. Treatments applications were decided based on three parameters: a) CLM infestation around 30\%, b) presence of instars I and II of CLM larvae c) Flushing greater than 60\%. Treatments were applied with a motorized knapsack sprayer Solo ${ }^{\mathrm{TM}}$, using the flow restrictor in the position four, which generated the expense of one liter of insecticide solution per tree. Evaluations took place each 48 hours until 10 days after the application of treatments. The repellent effect of neem on adults of CLM was calculated using the percentage of infestation in 20 fresh previously tagged shoots per useful tree and applying the formula cited by González et al., (1995):

$$
\% \text { of infestation }=\frac{\text { Number of leaves with live CLM larvae per shoot }}{\text { Number of leaves per shoot }} \times 100
$$

To establish CLM larvae mortality, prior to application of the treatments leaves without mines were eliminated in each tagged shoot, leaving only those with presence of live CLM larvae, of first instar, which is a stage suitable for A. citricola oviposition (Edwards and Hoy, 1998). A $10 \times$ magnifying glass was used to recognize the CLM larvae After the application of treatments, the selected shoots were protected with organdie bags, in order to avoid effect of predation and other parasitoids over CLM larvae. Larval mortality was determined visually in the field, using an OptiVisor ${ }^{\mathrm{TM}}$ magnifier glass (4X) and applying the formula cited by Tierto (1994):

$$
\% \text { of mortality }=\frac{\text { Number of dead insects }}{\text { Total population of the insect }} X 100
$$

The effect of neem on parasitism was determined based on the following variables: live larvae, dead larvae, adults emerged from CLM and pupa with evidence of parasitism, obtaining the percentage of parasitism in each evaluation, by the formula cited by Castaño (1996):

$$
\% \text { of parasitism }=\frac{\text { Number of biological stages of parasitoids }}{\text { Total number of biological stages }(\text { parasitoid }+ \text { pest })} \times 100
$$

This experiment was repeated three times during the dry season.

\section{Cage test}

This experiment was carried out at the "Portoviejo" Experimental Station of the National Institu-

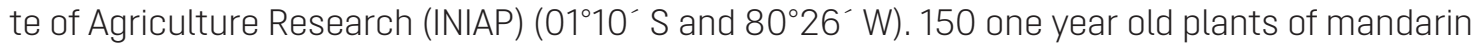


"Cleopatra" (C. reticulata) were placed in a cage $(2 \times 2 \times 2 \mathrm{~m})$ covered with organdie cloth, and were distributed in three groups of 50 plants per treatment, that were pruned a height of 50 $\mathrm{cm}$ with the purpose of stimulating the uniform emission of new shoots, free of CLM, after 15 days in the cage the plants had shoots of $5 \mathrm{~cm}$ which are ideal for infestation (Bautista, 1998). The same three treatments of the field test were assigned in a randomized complete design in which each plant was considered as an experimental unit; the treatments were applied using a manual backpack sprayer $\mathrm{CP}^{\mathrm{TM}}$ with a expense of $10 \mathrm{~mL}$ of the insecticide solution per plant, each group of plants was treated in different times to avoid contamination, after this process plants were immediately transported to an open field. They remained in a citrus orchard with historical records of high levels of CLM and parasitoids during eight days, in order to allow CLM infestation, larvae development until instar I and exposition to parasitoids. At the end of this period, the plants were moved back to the cage to suppress the risk of predation of CLM larvae. Neem repellency on CLM adults and parasitoids was determined, as well as CLM larval mortality by neem effect. The test was repeated twice (dry season and rainy season).

\section{Olfactometer test}

This trial was done in the laboratory of entomology in the "Portoviejo" Experimental Station (26 $\pm 2{ }^{\circ} \mathrm{C}$ and $75 \pm 5 \% \mathrm{RH}, 12$-h photoperiod). Neem repellency was studied using CLM adults. The test was repeated twice. It was applied the methodology described by Schuster et al.,(2009), using plastic olfactometers which consisted in transparent jars of a size of $20 \mathrm{~cm}$ in height by $16 \mathrm{~cm}$ in diameter, in the upper part it was made a hole of $3 \mathrm{~cm}$, which was covered later with a plug. Tests started every day at 6:00 h, using cutting discs (one per each olfactometer) of $C$. aurantifolia young leaves of $2.5 \mathrm{~cm}$ diameter, which were immersed in the same treatments of field test for 10 seconds, then placed in a mesh for 30 minutes for drying. Later they were collocated in the hole located at the top of each olfactometer (inside the plug) and supported with a mesh. Evaluations began at 7AM and from this first record, data was taken at 1, 2, 3, 4, 5, 6, 7, $8,9,10,11,12$ and 24 hours after. The only variable recorded was the number of adults perched on the leaf disc, one replicate per day, with a total of five biological replicates of the experiment, each one was considered as a repetition in a completely randomized design, the experimental unit was a olfactometer with 20 unsexed newborn ( $<24 \mathrm{~h})$ adults of CLM. The percentage of repellency was calculated whit the formula used by Olivero et al., (2009):

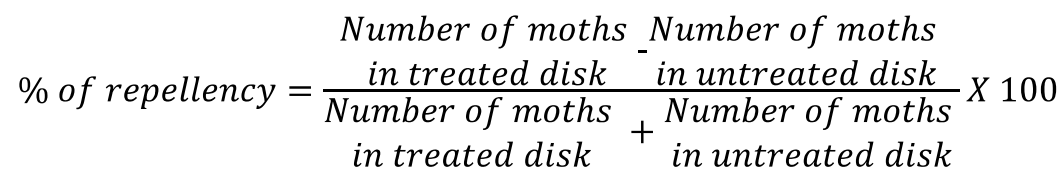

\section{Preparation and application of treatments}

For the treatment with aqueous extract, the operation was controlled from the harvest to the processing of the mature neem seed, which was harvested and immediately processed (deshelled, washed with water and dried at room temperature for five days), under these conditions the seed was ready to be ground. In each application the necessary amount of seed was ground and mixed with water, 24 hours later this solution was strained twice (with the objective of avoid blocking of 
the nozzles of the sprayer) and applied at the concentration of $50 \mathrm{~g} \mathrm{~L}^{-1}$. For the neem oil treatment it was used the commercial formulated oil INBIO $75^{\mathrm{TM}}$ at the concentration of $10 \mathrm{~mL} \mathrm{~L}^{-1}$.

\section{Statistical analysis}

Data was analyzed with the Statistical Analysis program, Version 6.12 (SAS Institute, 1988), Tukey mean separation test was applied to variables that showed statistical differences $(p \leq 0.05)$.

\section{Results and Discussion}

\section{Field test}

Neem repellency to adult CLM populations was determined based on the percentage of infestation (Figure 1A). Tukey test detected in all replicates that the aqueous extract and formulated neem oil treatments differ statistically from the control, which presents up to $47.96 \%$ infestation in replicate one. In replicate three, it is observed that statistically the aqueous extract differs from the other two treatments, presenting the lowest infestation (11.97\%), followed by the neem oil formulated with $18.41 \%$. This suggests that neem acts as a repellent for adults of CLM, by keeping it away from the plant by olfactory or gustatory ways, interfering with its oviposition (Botanical Agricultural Insecticide, 1996). This is also consistent with the work of Zhang et al., (1994) in China, who applying neem oil in concentration of $1.4 \%$, obtained infestations lower than $10 \%$, while the control reached $97 \%$.

Larval mortality in plots treated with neem differ statistically from the control in the three trials, presenting continuously a high value, which reaches $77.17 \%$ in the aqueous extract and $68.96 \%$ in the oil (Figure 1B), concordant with Bautista (1997), who states that the aqueous extract of neem $\left(50 \mathrm{gL}^{-1}\right)$ causes a mortality of $70.56 \%$ between 48 and 72 hours after application, while Valarezo and Cañarte (1998) report a mortality of the formulated oil (Inbio $75^{\mathrm{TM}}$ ) higher than $80 \%$ until 12 days after application. It was also determined in this study that larval mortality began 48 hours after application and reached its maximum effectiveness ten days after application. The onset of neem mortality 48 hours after application, suggest that either as an extract or formulated oil, neem acts as an anti-feedant on the larvae of this pest. The limonoids contained in the neem paralyze the muscles of the jaws, interfering with the feeding process and eventually causes the death of the insect (Botanical Agricultural Insecticide, 1996). The anti-feeding action is manifested in the gastro-intestinal tract of the insect, so the ingested azadirachtin, causes disorders in the process of digestion and assimilation, this effect was confirmed by Ghoneim and Hamadah (2017) in an experiment with Spodoptera littoralis, in which they found that larvae treated with neem, defecated a significative lower amount of pellets that control ones. Another favorable and complementary characteristic of neem is its translaminar action (Botanical Agricultural Insecticide, 1996). Action that allows it to reach the walls of the parenchyma where the larva feeds, causing disorders in the process of protein synthesis (Sponagel, 1997).

The biological effectiveness shown by neem on CLM larvae interferes with the parasitoid population (Figure 1C). Treatment means in the last evaluation for the parasitism variable show statistical differences between neem and control, which presented significantly higher parasitism percentages $(66.04 \%, 62.26 \%$ and $53.30 \%)$ for tests 3, 2 and 1 respectively. On the other hand, it was determined that being the treatments with neem statistically different to 
the control, also between them there are statistical differences, presenting the treatment with aqueous extract the lowest percentage of parasitism (not greater than $12.42 \%$ ) in test 3; while neem oil reached a parasitism of $23.30 \%$ in test 1 . The variation of parasitism between neem treatments is related to the differential mortality of larvae that present, since the aqueous extract presented a higher mortality, reducing the possibilities of establishment and development of parasitoids due to the suppression of the host. The parasitoid A. citricola was found parasitizing more than $50 \%$ of CLM larvae in the control treatment and knowing that neem is responsible for high mortality of larvae, it also interferes with A. citricola, eliminating it during its development on the larva of CLM, This is verifiable when observing the Figure 1D, the control treatment always presents a significative higher percentage of CLM pupae (38.11\%, 31.95 \% and $25.11 \%)$, and that corresponds to those larvae that escape the action of parasitoids.

\section{Cage test}

The significant differences between neem treatments and the control are showed in Figure 2A which had the highest average of infestation (42.58 \% and $37.01 \%)$ in the two tests. The neem treatments were statistically similar, with the lowest infestation in the aqueous extract (13.87 $\%)$ in test 1 , and the oil $17.79 \%$ in test 2.

According to Tukey's test, there are differences in larval mortality between neem treatments and the control that presented a mortality of $4.21 \%$ in test 1; while between neem treatments there were no statistical differences, presenting the aqueous extract $16.91 \%$, and neem oil $13.43 \%$ of mortality (Figure 2B). These low percentages of CLM mortality would be explained due to the ten days lasted between the application of treatments and the presence of first instar larvae (Valarezo and Cañarte, 1997), a period in which the persistence of nim in treated leaves is low and therefore their insecticidal action on the larvae is reduced.

Similarly, while it is true that there were not high percentages of mortality, the repellent effect of these substances on the adult population of the CLM was confirmed, repellency that may have spread to parasitoids, because when observing the mean parasitism of the two tests (figure 2C), it is clear that in test 1 the three treatments are different from each other, the control presenting the highest percentage of parasitism $(75.50 \%)$, which is very different from neem oil (18.48 \%) and aqueous extract with $8.23 \%$. In test 2, the control had a higher parasitism $(73.61 \%)$, while neem treatments did not differ statistically among them, presenting both low percentages. This comparison of means suggest that the secondary compounds emitted by neem also have a repellent effect upon the parasitoid, considerably reducing the population of this beneficial organism. This assertion is supported by numerous studies on the mechanisms of action of neem in insects, which say that when a plant is sprayed with neem-based products, from the treated surface olfactory messages are emitted that prevent pests from colonizing it. Therefore, the rate of oviposition is reduced, either by the decrease in the population of ovipositing females, or by the anti-oviposition effect of neem in females that colonize and feed on a treated plant. This is consistent with Bezzar et al., (2016), who in their experiments found that larvae of Drosophila melanogaster exposed to neem, became adults with a significant lower amount of eggs that the unexposed ones.

Figure $2 \mathrm{D}$ shows the differences between the treatments for the emergency percentage variable of adults in CLM. In both tests the control had a significative lower percentage of emergency that fluctuated between 20.29 and 23.18 respectively. The neem treatments (extract and oil) had more than $68 \%$ of adult emergency. These results suggest that neem treated plants repelled the 
arrival of parasitoids, allowing the normal development of the pest, while in the control parasitoids did not have interference for attacking the CLM larvae. The greater adult emergence in larvae treated with neem is also favored by the low mortality that presents when it is applied before infestation.

\section{Olfactometer test}

Tukey test to average number of adults of CLM perched on treated leaf disc, stablished that neem treatments are statistically different from the control in all evaluations and tests (Figure 3). The neem treatments do not differ statistically between them, in test 1 the aqueous extract had a maximum average of adults (1.60) at 12 hours, followed by neem oil that at 8 hours presented 2 adults, and while in the control were presented at 12 and 24 hours an average of 15.60 adults (Figure 3A). These results were confirmed in test 2: the control reached up to 14.20 adults posed at 12 and 24 hours, a situation very contrasting with neem treatments, where the maximum number of adults posed was 1.80 in neem oil at 24 hours and 1.40 adults at 8 hours in the aqueous extract (Figure 3B). These results agree with those previously found in this research, regarding to the repellent action that neem exerts on the adult populations of CLM, either in aqueous extract or formulated oil. Once this repellent effect was statistically verified, the values were transformed to percentage in the two tests. It was determined that both the aqueous extract and the formulated neem oil have, on average, very similar repellency, this being $85.68 \%$ and $85.64 \%$ for the extract and oil formulated, respectively in test 1 , a situation that is confirmed in test 2 , where on average a repellency was obtained for the aqueous extract of $88.80 \%$ and $83.46 \%$ for the formulated oil of neem.

Figure 1. Field test, percentages of $A$ ) infestation of CLM, B), mortality of CLM, C) parasitism (A. citricola) and D) pupation of $P$. citrella
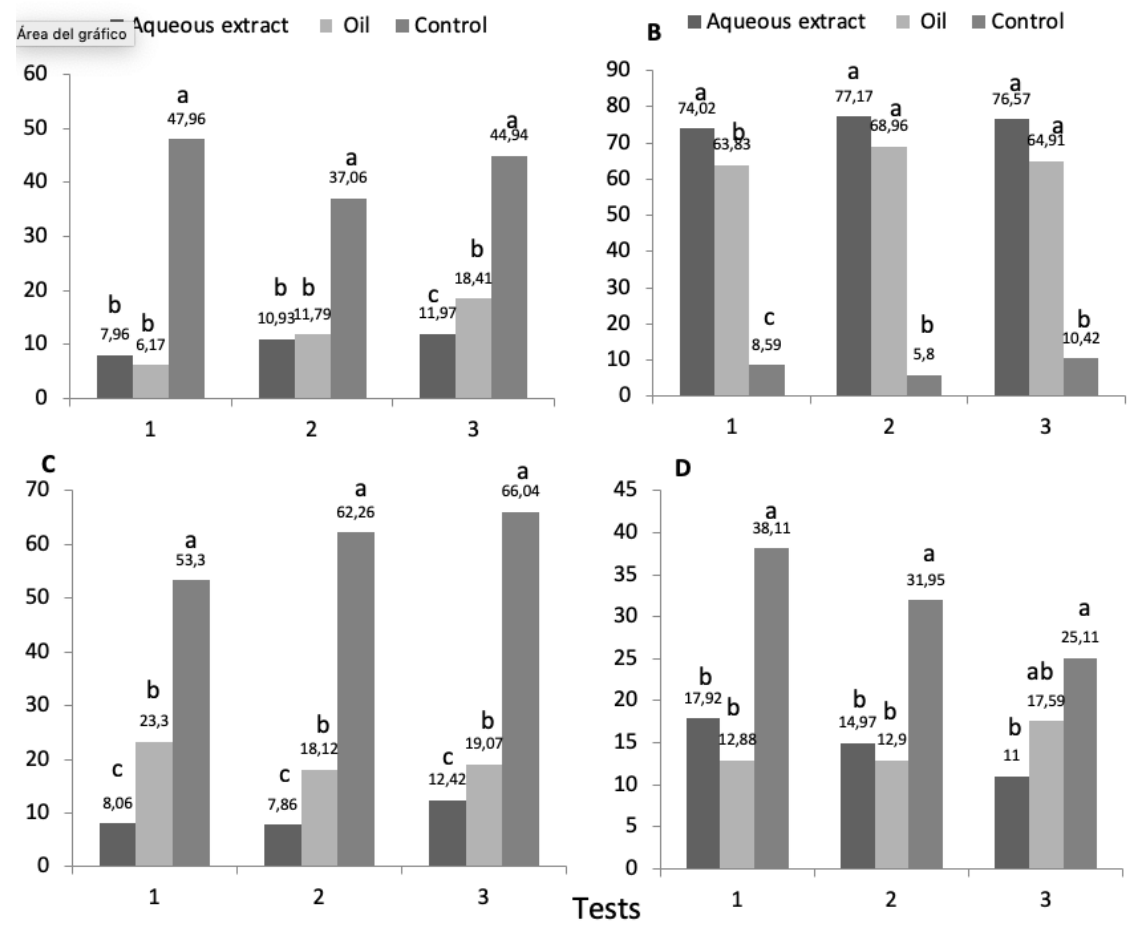
Figure 2. Cage test, percentage of $A$ ) infestation of CLM, B) mortality of CLM, C) parasitism (A. citricola), D) adult emergence of $P$. citrella
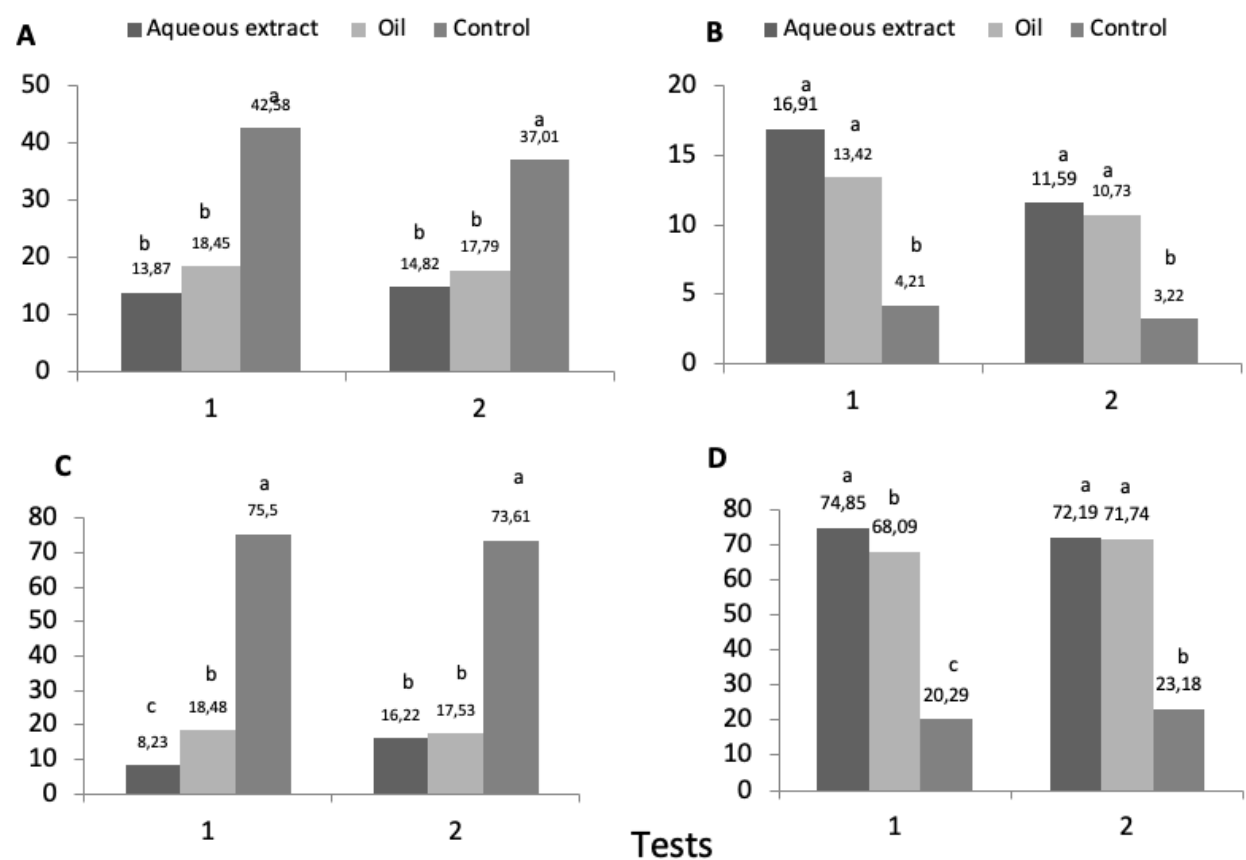

Figure 3. Olfactometer test, number of adults perched in leaf discs after the treatments. A) test 1, B) test 2

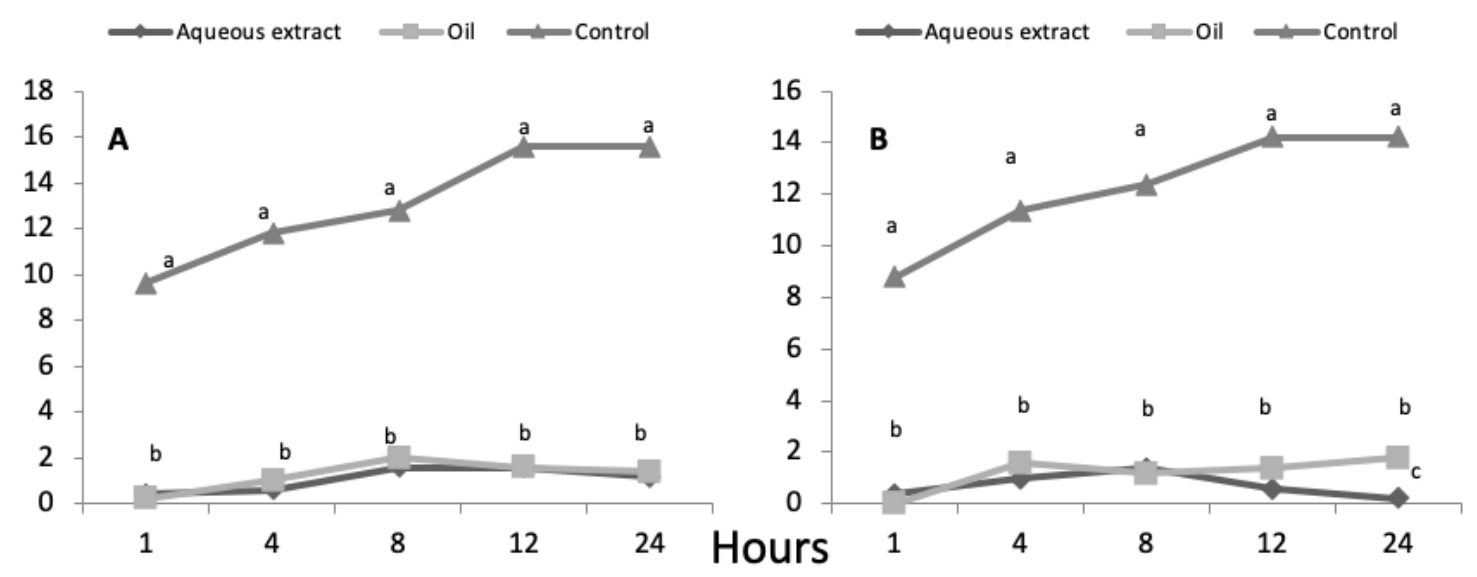

\section{Conclusions and recommendations}

The neem extract caused the highest larval mortality $(77.71 \%)$ and adult repellency of $P$. citrella $(88.80 \%)$, keeping this effect until ten days after the application of treatments. However, these effects interfered with the action of its main parasitoid $A$. citricola, repelling it and reducing its 
possibilities of establishment and development due mainly to the suppression of its natural host. For this reason, it is recommendable to avoid the use of neem when A. citricola is present in high population in the citrus field.

\section{Acknowledgements}

We thank the organizers of the "Il Simposio de Producción Integrada de Frutas 2019" for let us present this work in the meeting.

\section{Bibliography}

Arshad, M., Ullah, M., Afzal, M., Iftikhar, Y., Khalid, S., Hussain, Z., Molina-Ochoa, Jaime. and Foster, J. (2019). Evaluation of Synthetic Insecticides and Essential Oils for the Management of Phyllocnistis citrella Stainton (Lepidoptera: Gracillariidae). Pakistan Journal of Zoology, 51(3): 1053-1058.

Arshad, M., Ullah, M., Qureshi, J. andAfzal, M (2018). Physiological Effects of Citrus Leafminer Phyllocnistis citrella (Lepidoptera: Gracillariidae) Larval Feeding on Photosynthetic and Gaseous Exchange Rates in Citrus. Journal of Economic Entomology, 111(5): 2264-2271. https://doi.org/10.1093/jee/toy150

Bautista, N. (1997). Bioecología de Phyllocnistis citrella Stainton. Minador de la hoja de los cítricos (Lepidoptera: Gracillariidae). Tesis Doctor en Ciencias. Especialidad de Entomología y Acarología. Instituto. Fitosanidad., México: Colegio de Postgraduados.

Beattie, A. and Hardy, S. (2004). Citrus leafminer Agfact H2.AE.4. Sidney: Department of Primary Industries.

Bezzar, R., Kilani, S. andAribi, N. (2016) Larval exposure to azadirachtin affects fitness and oviposition site preference of Drosophila melanogaster. Pesticide Biochemistry and Physiology, 133: 85-90.

Borad, P., Patel, M., Vaghela N., Patel, B., Patel, M., andPatel, J. (2001). Evaluation of some botanicals against citrus leafminer (Phyllocnistis citrella) and psyla (Diaphorina citri) on kagzilime (Citrus aurantifolia), Indian Journal of Agricultural Science, 71: 177-179.

Botanical Agricultural Insecticide. (1996). Neem-X. A New Insect Control Weapon. Port Charlotte: USA.

Cañarte, E., Bautista, N., Vera, J., Arredondo, H., \& Huerta, A. (2004). Phyllocnistis citrella (Lepidoptera: Gracillariidae) and its parasitoids in citrus in Ecuador, Florida Entomologist, 87 (1): 10-17.

Cañarte, E., Valarezo, O., Navarrete, B., and Bautista M., N. (2005). Control biológico del minador de la hoja de los citricos Phyllocnistis citrella: Estudio del caso Ageniaspis citricola en Ecuador. Portoviejo: INIAP.

Castaño, O. (1996). El minador de la hoja de los cítricos (Phyllocnistis citrella) In: XXII Congreso Sociedad Colombiana de Entomología. Cartagena de Indias: Universidad de Caldas.

Colmenarez, Y., Corniani, N., Mundstock, S., Sampaio, M. and Vásquez, C. (2018). Use of Parasitoids as a Biocontrol Agent in the Neotropical Region: Challenges and Potential. Retrieved from https:// www.intechopen.com/online-first/use-of-parasitoids-as-a-biocontrol-agent-in-the-neotropical-region-challenges-and-potential (accessed 25/08/2019).

Dubreuil, N., Ottomani, M., Gilles, T., Kreiter, P. (2018). Réduction des intrants phytosanitaires en vergers de kiwis et de clémentines en Corse. Innovations Agronomiques, 70: 87-104.

Edwards, O. and Hoy, M. (1998) Biology of Ageniaspis citricola (Hymenoptera: Encyrtidae), a Parasitoid of the Leafminer Phyllocnistis citrella (Lepidoptera: Gracillariidae). Annals of the Entomological Society of America,91(5), 654-660. doi:10.1093/aesa/91.5.654

Faisal- Shareef, M., Raza, A.,Majeed, M., Ahmed, K., Raza, W. and Hussain, H. (2016). Effect of botanicals on the infestation of citrus leaf miner Phyllocnistis citrella Stainton. Journal of Entomology and Zoology Studie, 4(4): 1335-1340.

Francesena, N.and Schneiderab, M. (2018). Selectivity assessment of two biorational insecticides, azadirachtin and pyriproxyfen, in comparison to a neonicotinoid, acetamiprid, on pupae and adults of 
a Neotropical strain Eretmocerus mundus. Mercet. Chemosphere, 206: 349-358. https://doi. org/10.1016/j.chemosphere.2018.05.010

Ghoneim, K., and Hamadah, K. (2017). Antifeedant activity and detrimental effect of Nimbecidine (0.03\% Azadirachtin) on the nutritional performance of Egyptian cotton leafworm Spodoptera littoralis Boisd. (Noctuidae: Lepidoptera). Bio Bulletin, 3(1): 39-55.

González, C., Borges, M., Castellaños, A., González, N., Vázquez, L., and García, M. (1995). Phyllocnistis citrella. Minador de la Hoja de los Cítricos In: Il Taller nacional sobre el minador de la hoja de los cítricos. La Habana: Instituto de Investigaciones de Cítricos.

Gottwald, T., Bassanezi, R., Amorim, L. and Bergamin-Filho, A. (2007). "Spatial pattern analysis of citrus canker-infected plantings in Sao Paulo, Brazil, and augmentation of infection elicited by the Asian leafminer". Phytopathology, 97(6): 674-83. doi: 10.1094/PHYTO-97-6-0674.

Grafton-Cardwell, E., Godfrey, K., Headrick D., Mauk, P. and Peña, J. (2008). "Citrus Leafminer and Citrus Peelminer". Retrieved from https://anrcatalog.ucanr.edu/pdf/8321.pdf (accessed 25/08/2019).

Green, H., Broun, P., Cakmak, I., Condon, L., Fedoroff, N., Gonzalez-Valero, J., Graham, I., Lewis, J., Moloney, M., Oniang'o, R., Sanginga, N., Shewry, P. and Roulin, A. (2016). "Planting seeds for the future of food". Journal of the science of food and agriculture, 96(5): 1409-1414. doi: 10.1002/jsfa.7554

Hummel, H., Hein, D., Ley, S., Morgan, E., Kraus, W. andSchmutterer, H. (2011). Twenty five years of azadirachtins(1986- 2011), Pestycydy/Pesticides 1(4): 49-56.

Ogbuewu, I., Odoemenam, V., Obikaonu, H., Opara, M., Emenalom, O., Uchegbu, M. Okoli, B. (2011). "The Growing Importance of Neem (Azadirachta indica A. Juss) In Agriculture, Industry, Medicine and Environment: A Review." Research Journal of Medicinal Plants, 5(3): 230-245. doi: 10.3923/ rjmp.2011.230.245.

Olivero, J., Caballero, K., Jaramillo, B. and Stashenko, E. (2009). Actividad repelente de los aceites esenciales de Lippia origanoides, Citrus sinensis y Cymbopogon nardus cultivadas en Colombia frente a Tribolium castaneum, Herbst. Revista Universidad Industrial de Santander. Salud, (41) 3: 244-250.

Sarada, G., Gopal, K., Gouri, T., Mukunda, L., Gopi, V., Nagalakshmi, T. and Ramana, K. (2014). Citrus Leaf Miner (Phyllocnistis citrella Stainton, Lepidpptera: Gracillariidae): Biolology and Management: A Review. Journal of Agriculture and Allied Sciences, 3(3): 39-40.

SAS Institute. (1998). Language Guide for Personal Computer release. 6.03 ed. SAS Institute, Cary, North Carolina, USA.

Schuster, S., Thompson, L., Ortega, D. and Polston, E. (2009). Laboratory evaluation of products to reduce settling of sweetpotato whitefly adults. Journal of Economic Entomology,102 (4): 1482-1489.

Sponagel, K. (1997). Propuesta de desarrollo para actividades agroecológicas de CEMADEC con énfasis en el uso del árbol nim. Quito, Corporación PROEXANT.

Tierto, N. (1994). The ability of powders and slurries from ten plant-species to protect. Stored grain from attack by Prostephanus truncatus (Coleoptera: Bostrichidae) y Sitophilus oryzae (Coleoptera: Curculionidae). Journal of Stored Products Research, 30(4): 297-301.

Valarezo, O. and Cañarte, E. (1998). El minador de la hoja de los cítricos Phyllocnistis citrella en el Litoral ecuatoriano. Portoviejo: INIAP-COSUDE.

Valarezo, O., Cañarte, E. y Navarrete, B. (2004). Distribución, bioecología y manejo de Phyllocnistis citrella Stainton en Ecuador. Portoviejo: INIAP-PROMSA.

Valarezo, O., Cañarte, E. and Navarrete, B. (2008). El nim: Insecticida botánico para el manejo de plagas agrícolas. Portoviejo. INIAP.

Yanard, D. (2019). "Side effects of different doses of azadirachtin on predatory mite Metaseiulus occidentalis (nesbitt) (Acari: Phytoseiidae) under laboratory conditions. Applied ecology and environmental research. 17(2): 3433-3440 http://dx.doi.org/10.15666/aeer/1702_34333440

Zhang, A., O'Leary, C. and Quarles, W. (1994). Chinese IPM for citrus leafminer. Practioner, 16(8): 10-13. 